\title{
Cutaneous Malignancies in Tattoos, a Case Series of Six Patients
}

\author{
Marike Leijs ${ }^{1,2, *} \mathbb{0}$, Hannah Schaefer ${ }^{2}$, Albert Rübben ${ }^{1,2} \oplus$, Claudio Cacchi $^{3}$, Thomas Rustemeyer ${ }^{4}$ \\ and Sebastiaan van der Bent ${ }^{5}$ \\ 1 Department of Dermatology, St. Nikolaus Hospital, 4700 Eupen, Belgium; \\ Albert.Ruebben@post.rwth-aachen.de \\ 2 Department of Dermatology and Allergology, RWTH Aachen University, 52074 Aachen, Germany; \\ hannah.schaefer@rwth-aachen.de \\ 3 Institute of Pathology, RWTH Aachen University, 52074 Aachen, Germany; ccacchi@ukaachen.de \\ 4 Academic Tattoo Clinic Amsterdam, Department of Dermatology and Allergology, Amsterdam UMC, \\ 1081 HV Amsterdam, The Netherlands; t.rustemeyer@amsterdamumc.nl \\ 5 Tattoo Clinic (Tattoo Poli), Department of Dermatology, Alrijne Ziekenhuis Leiden, 2334 CK Leiden, \\ The Netherlands; sasvanderbent@alrijne.nl \\ * Correspondence: mleijs@ukaachen.de
}

check for

updates

Citation: Leijs, M.; Schaefer, H.; Rübben, A.; Cacchi, C.; Rustemeyer, T.; van der Bent, S. Cutaneous Malignancies in Tattoos, a Case Series of Six Patients. Curr. Oncol. 2021, 28, 4721-4737. https://doi.org/10.3390/ curroncol28060398

Received: 21 September 2021

Accepted: 9 November 2021

Published: 15 November 2021

Publisher's Note: MDPI stays neutral with regard to jurisdictional claims in published maps and institutional affiliations.

Copyright: (c) 2021 by the authors. Licensee MDPI, Basel, Switzerland. This article is an open access article distributed under the terms and conditions of the Creative Commons Attribution (CC BY) license (https:// creativecommons.org/licenses/by/ $4.0 /)$.

\begin{abstract}
Background: A variety of side effects following the tattooing of the skin were reported over the years. Analytical studies showed that some tattoo inks contain harmful compounds. Methods: We presented six patient cases with cutaneous malignancies in tattooed skin and performed an extensive literature research. Results: Two patients with black ink tattoos that were diagnosed with malignant melanoma raises the number of described cases to 36 patients. One of the patients developed an immunologic reaction limited to the tattoo area after treatment with a targeted immune therapy. In the other patient, the malignancy (malignant melanoma) was fatal. Basal cell carcinoma was seen in four patients with tattoos containing varying ink colors (black, green, red). This increased the number of described patient cases to 18. Although some ink components and their cleavage products have carcinogenic properties, epidemiological evidence for a causative correlation fails. Further epidemiologic studies on tattoos and malignancies, as well as on the appearance of naevi in tattoos, are necessary. Determining the type of mutation might be helpful to separate sun-induced tumors from skin cancers due to other pathogenic mechanisms.
\end{abstract}

Keywords: tattoo; tattoo ink; melanoma; basal cell carcinoma; squamous cell carcinoma; polyaromatic hydrocarbons; tumor promotion; endocrine disruptors

\section{Introduction}

Tattooing is defined as the artificial introduction of exogenous pigments into the dermis [1]. Both the incidence of tattoos and malignant melanoma have shown an extreme increase in recent decades [2-5]. The occurrence of tattoos in industrial countries reaches up to $36 \%$ of the German population, and $24-46 \%$ of the population of the USA are tattooed $[3,6]$. Especially, young respondents were more likely to have even multiple tattoos $[3,5,7]$.

Meanwhile, several adverse events are reported on tattooed skin [7,8]. These include not only type IV allergic reactions (allergic contact dermatitis), but also skin cancer $[7,9,10]$. Other non-malignant adverse events include infections, scars, keloid, blow-out and the occurrence of auto-immune skin diseases such as sarcoidosis and psoriasis [11-13].

The complications of infectious origin include bacterial infections of the skin (most common: staphylococcus, streptococcus, Pseudomonas aeruginosa and Escherichia coli) and viral infections in the formation of various skin lesions (human papilloma virus, pox virus, herpes virus). In addition, serious infectious diseases such as the human immunodeficiency virus (HIV) or hepatitis virus (Hep. B/C) might be transmitted during tattooing [12]. 
Since 1938 [5,14], several benign and malignant skin lesions occurring in tattoos have been reported [10,14-18]. Malignant lesions of the skin reported in tattooed areas included malignant melanoma, basal cell carcinoma, squamous cell carcinoma, dermatofibrosarcoma protuberans, lymphoma and keratoacanthoma [19]. A total of 36 cases (32 male and 3 female, $1 \mathrm{NA}$ ) of malignant melanoma arising in tattoos were reported (Table 1). 
Table 1. Reported cases of malignant melanoma, basal cell carcinoma, squamous cell carcinoma and keratoacanthoma in tattooed skin.

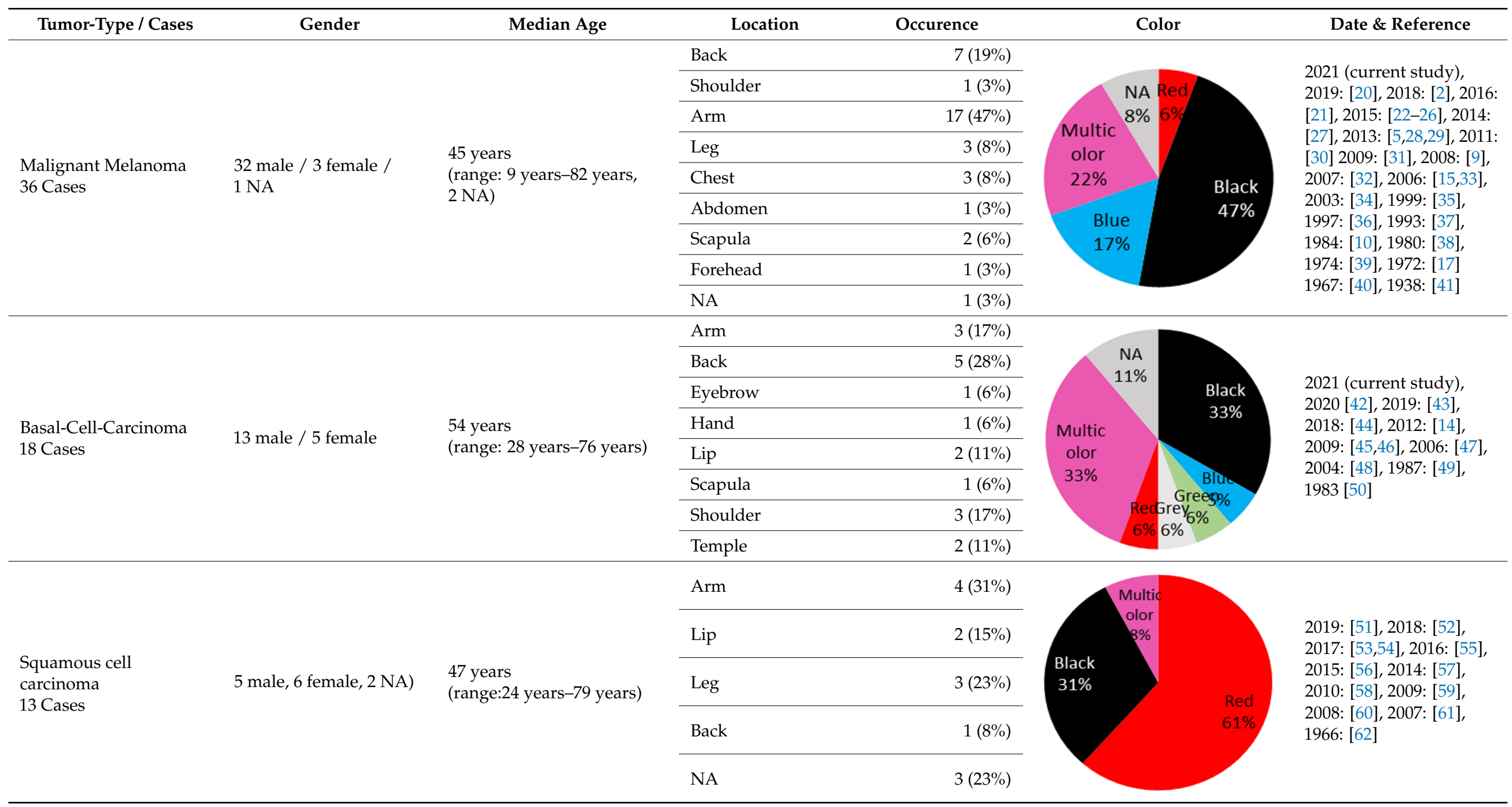


Table 1. Cont.

\begin{tabular}{|c|c|c|c|c|c|c|}
\hline Tumor-Type / Cases & Gender & Median Age & Location & Occurence & Color & Date \& Reference \\
\hline \multirow{5}{*}{$\begin{array}{l}\text { Keratoacantoma } \\
16 \text { Cases }\end{array}$} & \multirow{5}{*}{7 male, 5 female, 4 NA } & \multirow{5}{*}{$\begin{array}{l}54 \text { years } \\
\text { (range } 36 \text { years-72 years) }\end{array}$} & Scapula & $1(6 \%)$ & & \multirow{5}{*}{$\begin{array}{l}\text { 2020: [63], 2019: [64,65], } \\
\text { 2017: [65], 2010: [66], } \\
\text { 2009: [67], 2008: [68] }\end{array}$} \\
\hline & & & Leg & $3(19 \%)$ & & \\
\hline & & & Arm & $8(50 \%)$ & & \\
\hline & & & Shin & $2(13 \%)$ & & \\
\hline & & & Ankle & $2(13 \%)$ & & \\
\hline \multirow{3}{*}{$\begin{array}{l}\text { Dermatofibrosarcoma } \\
\text { protuberans } \\
5 \text { Cases }\end{array}$} & \multirow{3}{*}{3 male, 2 female } & \multirow{3}{*}{$\begin{array}{l}31 \text { years } \\
\text { (range: } 21 \text { years- } 37 \text { years, } \\
\text { 1NA) }\end{array}$} & Arm & $1(20 \%)$ & & \multirow{3}{*}{$\begin{array}{l}\text { 2020: [69], 2018: [70], } \\
\text { 2014: [71], 2011: [72], } \\
\text { 2005: [73] }\end{array}$} \\
\hline & & & Back & $2(40 \%)$ & & \\
\hline & & & N.A. & $1(20 \%)$ & & \\
\hline \multirow{5}{*}{$\begin{array}{l}\text { Cutaneous lymphoid } \\
\text { Hyperplasia } \\
6 \text { Cases }\end{array}$} & \multirow{5}{*}{3 male, 3 female } & \multirow{5}{*}{$\begin{array}{l}35 \text { years } \\
\text { (range: } 25 \text { years- } 67 \text { years) }\end{array}$} & Leg & $2(33 \%)$ & & \multirow{5}{*}{$\begin{array}{l}\text { 2014: [74,75], 2013: [76] } \\
\text { 2011: [77] 2009: [78] 2002: } \\
\text { [79] }\end{array}$} \\
\hline & & & Shoulder & $1(40 \%)$ & & \\
\hline & & & Back & $1(17 \%)$ & & \\
\hline & & & Ankle & $1(17 \%)$ & & \\
\hline & & & N.A. & $1(17 \%)$ & & \\
\hline $\begin{array}{l}\text { Cutaneous } \\
\text { leiomyosarcoma } \\
1 \text { Case }\end{array}$ & male & 41 years & Arm & $1(100 \%)$ & Black & 2009: [80] \\
\hline
\end{tabular}


Until today, the link between the clinical appearance of malignancies in tattoos and the containment of toxic compounds was not proven. Most tattoo inks consist not only of insoluble pigments but also additives, dispersants and preservatives. The toxicological risk of some of the used compounds is relatively unknown [81]. The predominantly used ink color is black (carbon black), often containing compounds such as potential genotoxic polyaromatic hydrocarbons (PAHs) [82]. Although today's ink compounds are assumed to contain less genotoxic compounds, they still consist mainly of pigments that were developed for other purposes (e.g., plastics, printing, textiles, cosmetics and even automotive coatings) and safety assessments/risk assessment are lacking [83]. Nevertheless, heavy metals still have a large proportion of tattoo ink [81]. An analysis of commercially used inks revealed that the most used colorants were titanium, barium, aluminum and copper $[84,85]$. However, it became clear that more harmful compounds such as antimony, arsenic, cadmium, chromium, cobalt, lead, and nickel were mostly present as contaminants $[81,84,85]$. The amounts of metals in the composition of tattoo inks seems highly variable between brands and colors, even in pigments with the same base color [86].

Eventually, about $10 \%$ of all tattooed individuals choose to remove their tattoo, mostly by using laser-assisted tattoo removal where the cleavage of tattoo ink occurs in largely unclear products. Even without laser-assisted removal, tattoos fade in time [87]. Pigments are most likely to be metabolized by enzymes such as azo reductases. Through such a pathway, the colorants might split in aromatic amines [87].

Due to the limited number of published cases of tumors in tattoos, there is insufficient epidemiological evidence for a correlation with (possible) harmful compounds in tattoo ink. With six case series and an overview of the literature, we increase the number of published cases and aim to broaden the pathophysiological knowledge on malignancies in tattoos and the possible role of tattoo ink.

\section{Materials and Methods}

\subsection{Study Cohort}

Retrospectively, we included patients, who developed a malignancy in their tattoo, from the Department of Dermatology and Allergology at the RWTH Aachen University in Aachen, Germany (2005-2020); the Department of Dermatology and Allergology, UMC Amsterdam in Amsterdam, The Netherlands (2015-2020), and the Department of Dermatology, Alrijne Ziekenhuis Leiden, The Netherlands (2021). A total of 6 patients (6 males) were included. Informed consent for the usage of photos was obtained for 5 of the patients. For one patient with malignant melanoma who died, no informed consent was possible since the contact details of the relatives were not valid anymore, so no clinical pictures of this patient were shown.

\subsection{Literature Research and Evaluation of the Data}

The literature study was performed in PubMed and Google Scholar with the following search terms: "tattoo(ing)" / "tattoo" and "ink" in combination with "melanoma", "malignant melanoma", "basal cell carcinoma", "squamous cell carcinoma”, "keratoacanthoma", "dermatofibrosarcoma protuberans" and "cutaneous leiomyosarcoma", , cancer", "allergy", "complication", "dyes", "heavy metals", "infection", " phototoxicity", " pigments", "preservatives", and "toxicology". The databases "PubChem" and "European Chemicals Agency" (ECHA) were used to gather information about the toxicity of the tattoo ink ingredients. The database on current cancer statistics of the Robert Koch Institute (RKI) was used to compare the characteristics of the published case studies with the general population in Germany. No further criteria were used to select the sources.

In our overview of the literature (Table 1), we present all the papers published up to this point with cases concerning malignancies in tattoos. Because of the scarce amount of papers published on this topic, apart from the correlation between the occurrence of malignant skin lesions in tattooed skin regions, there were no other inclusion criteria for the 
selection of the literature. The results of the literature search were summarized in tabular form. Details can be found in the Prisma flow diagram (Figure S1).

\section{Results}

We present six male subjects who developed malignancies in tattooed areas of the skin.

\subsection{Cases with the Formation of Melanoma in Tattooed Skin}

Patient 1: A 52-year-old man (smoker) presented to our clinic for a skin cancer screening in 2018. Although during the examination a suspicious skin lesion at the lower back was found, no other malignancies were found during an extensive skin examination. The patient reported that a skin lesion was already removed 18 years ago but re-appeared since. The patient reported no history of trauma. The examination revealed that the suspicious skin lesion was a $4 \times 6 \mathrm{~cm}$ large, irregularly pigmented, partly semi-circular maculae in the area of a tattoo (see Figure 1). We suspected a malignant melanoma and performed an excision of the lesion in toto. Histopathology revealed a superficially spreading malignant melanoma (SSMM) with a thickness of $0.7 \mathrm{~mm}$ (pT1a, N1a, M0, R0). Sequencing did not reveal pathogenic mutations in genes BRAF, NRAS or KIT. Subsequently, the SSMM was re-excised with $1 \mathrm{~cm}$ margins and, because of the size of the melanoma in combination with histopathological signs of regression, we decided to perform a sentinel lymph-node excision. There was a positive sentinel lymph node in the right groin containing micro metastasis up to $1.2 \mathrm{~mm}$, so the patient was diagnosed with stage IIIA (AJCC 2017) malignant melanoma. Subsequently, a right inguinal lymph node dissection was performed $(0 / 12)$ and an adjuvant immuno-therapy with Nivolumab (3 $\mathrm{mg} / \mathrm{kg}$ every 2 weeks) was given for 12 months. The patient was introduced to us again 5 months later with cutaneous side effects (toxicity grade 1 ) on the abdomen induced by the targeted immunotherapy with nivolumab. We examined palpable small papules in the area of the tattooed skin with emphasis on the black color. We suspected an immunological reaction in this area triggered by the black color ink, most likely a granulomatous skin reaction as seen in another study [88]. The patient presented himself to regular follow-up examinations and has had no recurrence of the SSMM to date.

Patient 2: The second case (33-year-old male) presented himself with a melanoma on the left shoulder blade/scapula (tumor thickness $6.0 \mathrm{~mm}$, Clark-level IV, pT4a). No other malignancies were found during an extensive skin examination. Anamnesis revealed that the lesion was not present before the placement of the tattoo. We performed an excision of the nodular malignant melanoma (NMM) in June 2005 (Figure 2). A benign melanocytic nevus within the tattoo was excised, and tattoo pigment was found in the same layer of the dermis as the nevus cells (Figure 3). Subsequently, the NMM was re-excised in July 2005, with $2 \mathrm{~cm}$ margins combined with a sentinel-node biopsy ( $3 / 4$ positive). Furthermore, a left axillary lymph node dissection revealed lymph node metastasis (9/20 positive) (Figure 4). We started a high-dose interferon therapy in March 2006, which was paused due to paresthesia in the fingertips between April and August 2006. In September 2007, multiple pronounced cerebral, cerebellar, cervical, abdominal and thoracic metastases were found. The patient was admitted to our clinic and we immediately started radiation therapy (10 sessions) and chemotherapy with Temozolomide $200 \mathrm{mg} / \mathrm{kg}$. Due to the above-mentioned, acute, life-threatening diagnosis we needed to stop the chemotherapy and give priority to radiation therapy in the range from $\mathrm{C} 7$ to $\mathrm{TH} 3$. In addition, a gamma knife irradiation of the cerebral and cerebellar metastases was carried out. Resumption of chemotherapy with Taxol and Carboplatin was planned for November 2007, but, unfortunately, the patient died shortly after. 


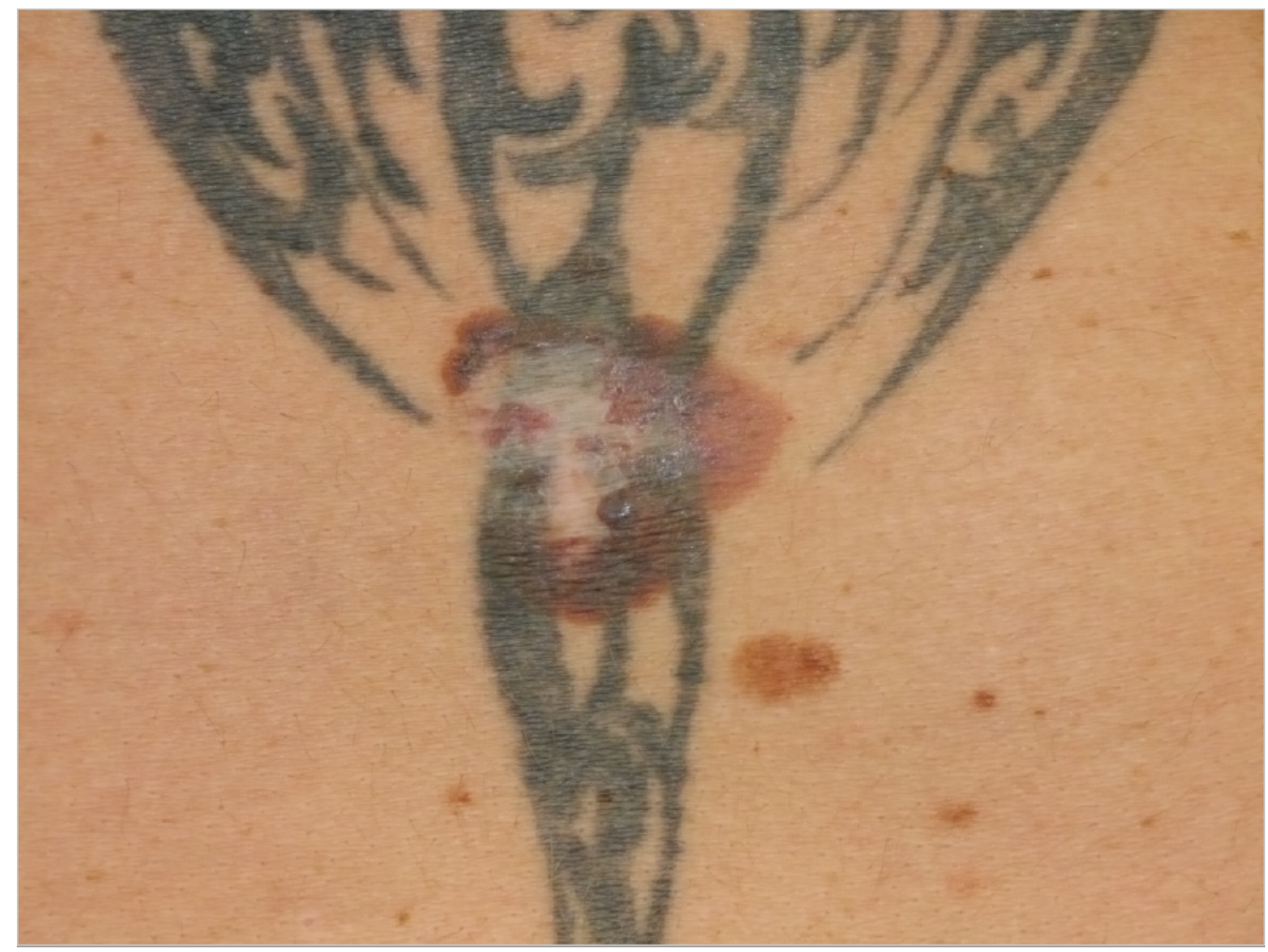

Figure 1. A recurrent skin lesion on the back which was previously removed 18 years ago.

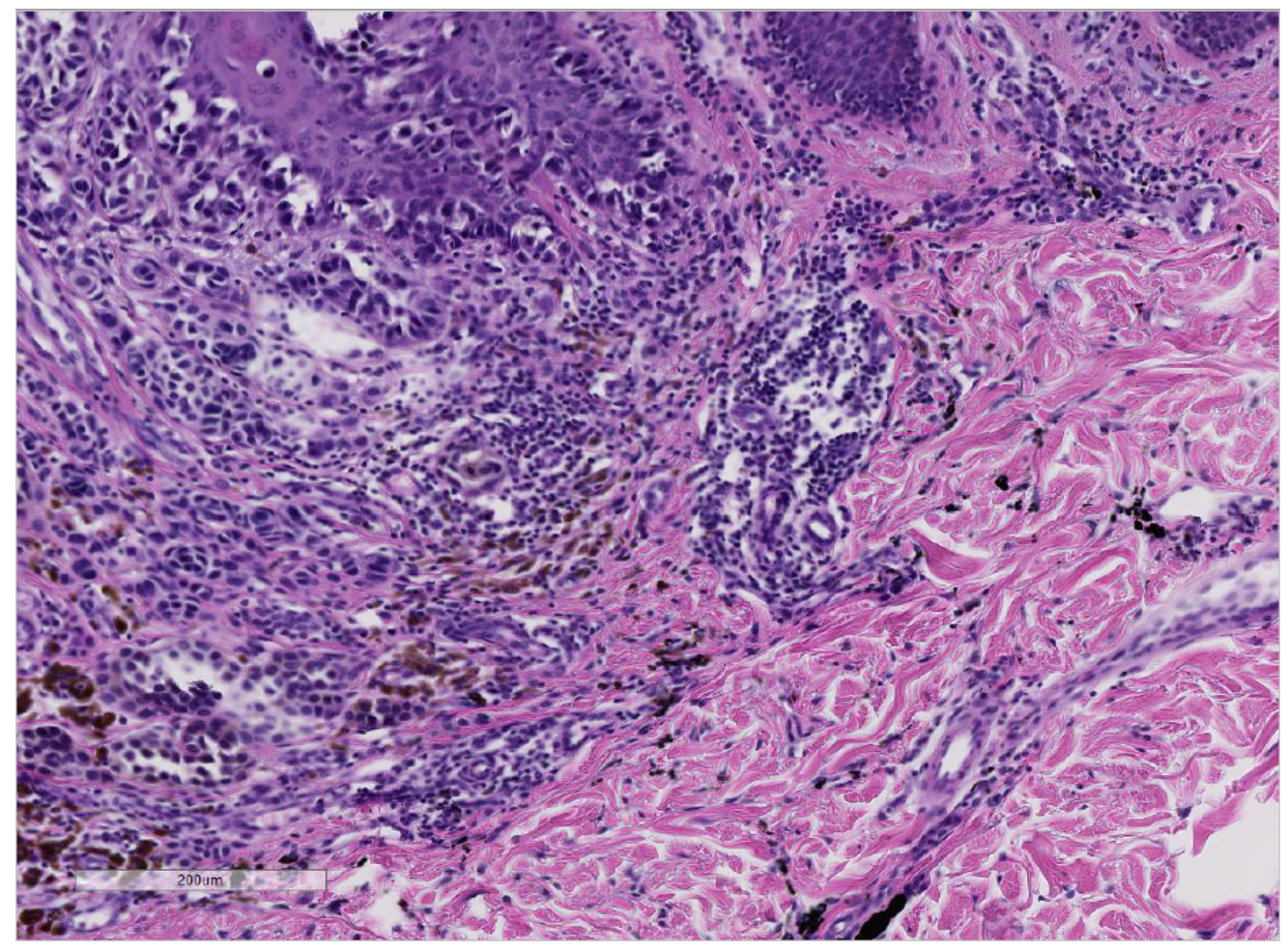

Figure 2. (Hematoxylin and Eosin 10×): Patient No. 2: the histology shows malignant melanocytes with atypia in the epidermis and in the dermis. Note the difference of color between melanin pigment (brown) and the black tattoo pigment (right/bottom). 


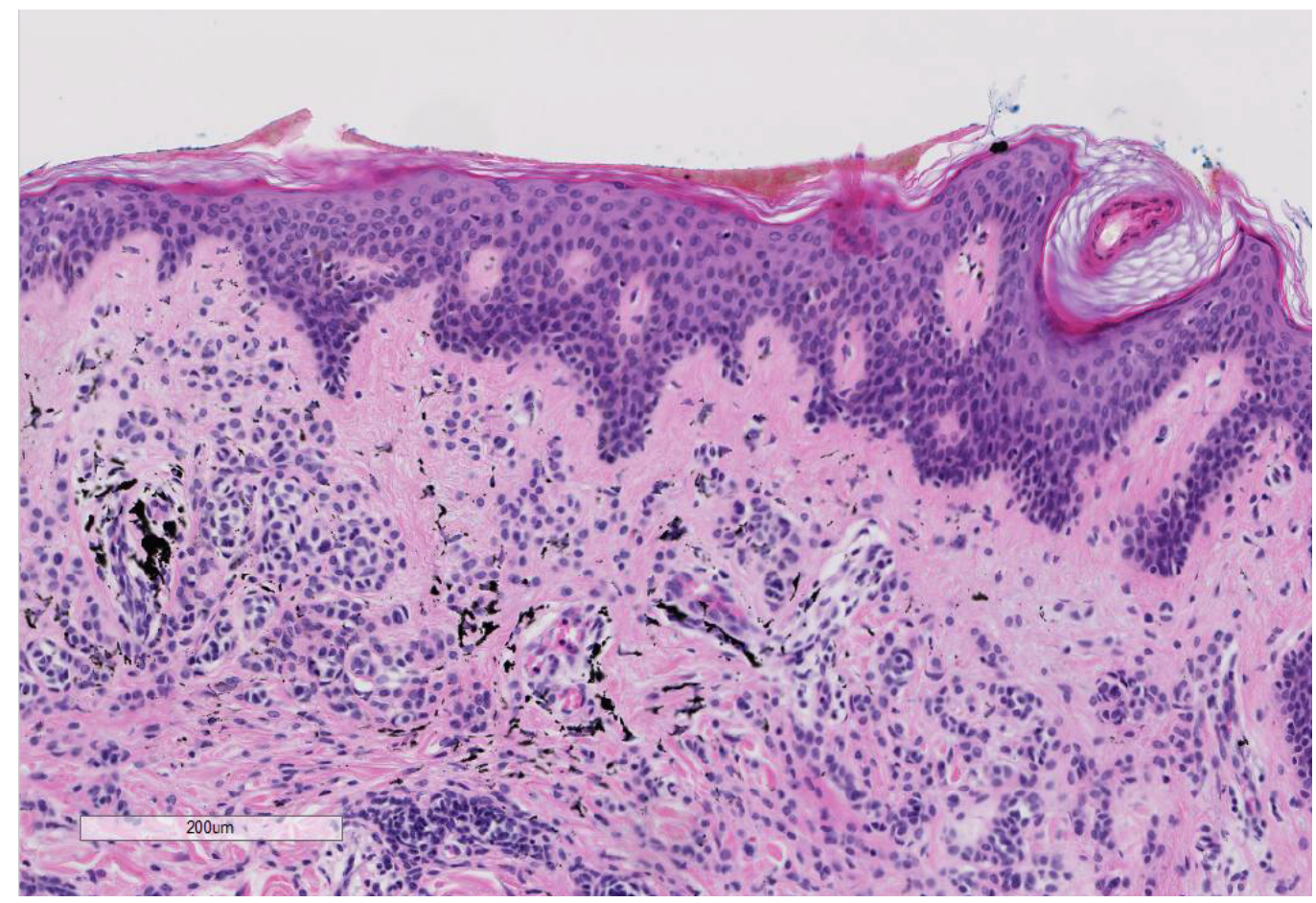

Figure 3. (Hematoxylin and Eosin 10×): A benign melanocytic nevus within the tattoo of patient No. 2: The slide shows benign small melanocytes without atypia in the in the dermis in association with the fine-granular black tattoo pigment.

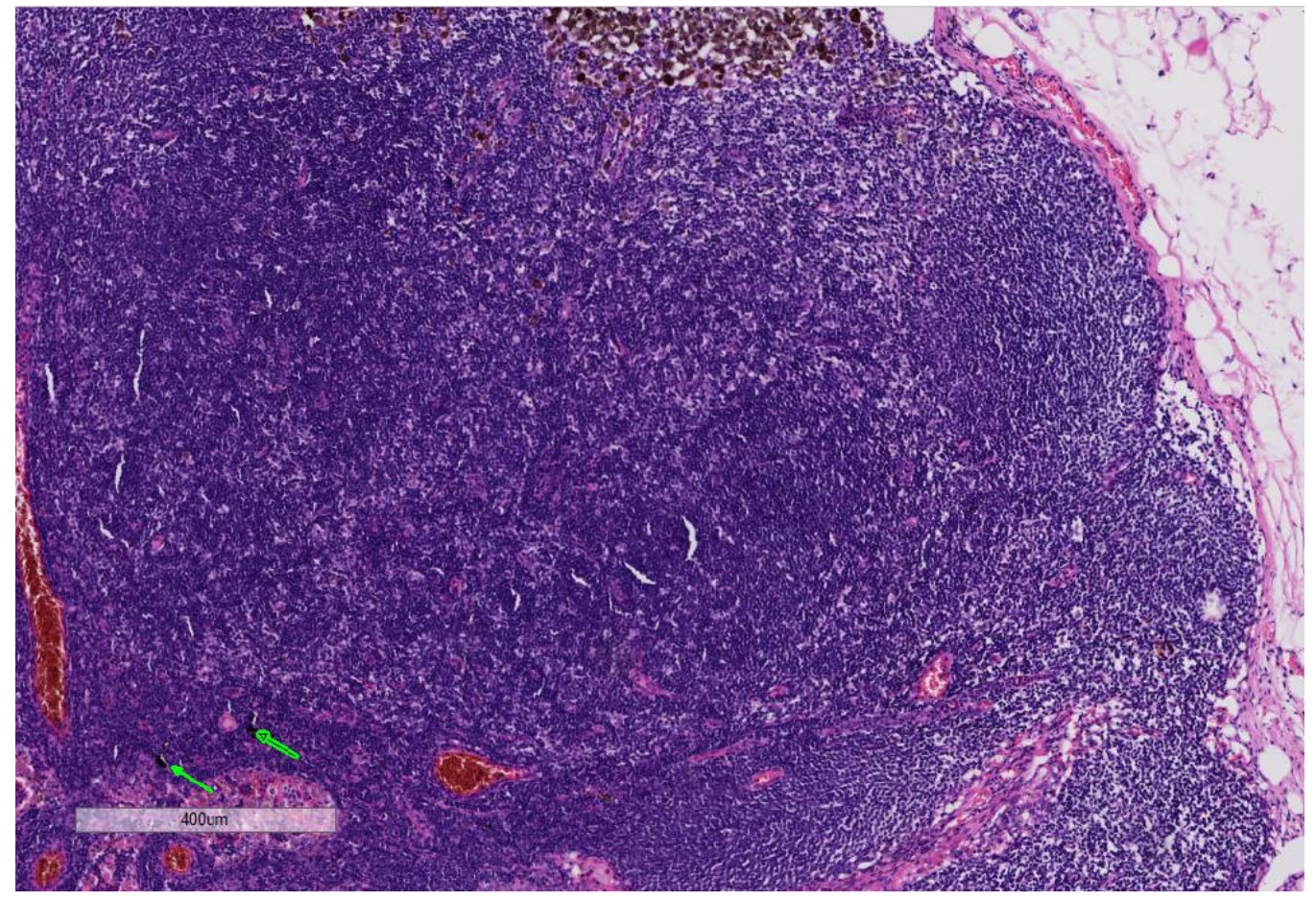

Figure 4. (Hematoxylin and Eosin 5×): Patient No 2: The slide demonstrates melanoma cells in the lymph node with brown melanin pigment and black ink in the same lymph node (arrows).

Sequencing was performed post mortem and did not reveal mutations in the BRAF gene. 


\subsection{Cases with the Formation of Basal Cell Carcinoma in Tattooed Skin}

Patient 3: A 57-year-old man visited the department of dermatology because of a 1.5-year-old lesion in his black tattoo on the right shoulder (see Figure 5). During a physical examination, we observed an erythematous glazing tumor with telangiectasia in the tattooed area. No other malignancies were found during an extensive skin examination. Anamnesis revealed the lesion was not present before placement of the tattoo. Histopathology of a skin biopsy showed a nodular basal cell carcinoma. The tumor was radically excised [13].

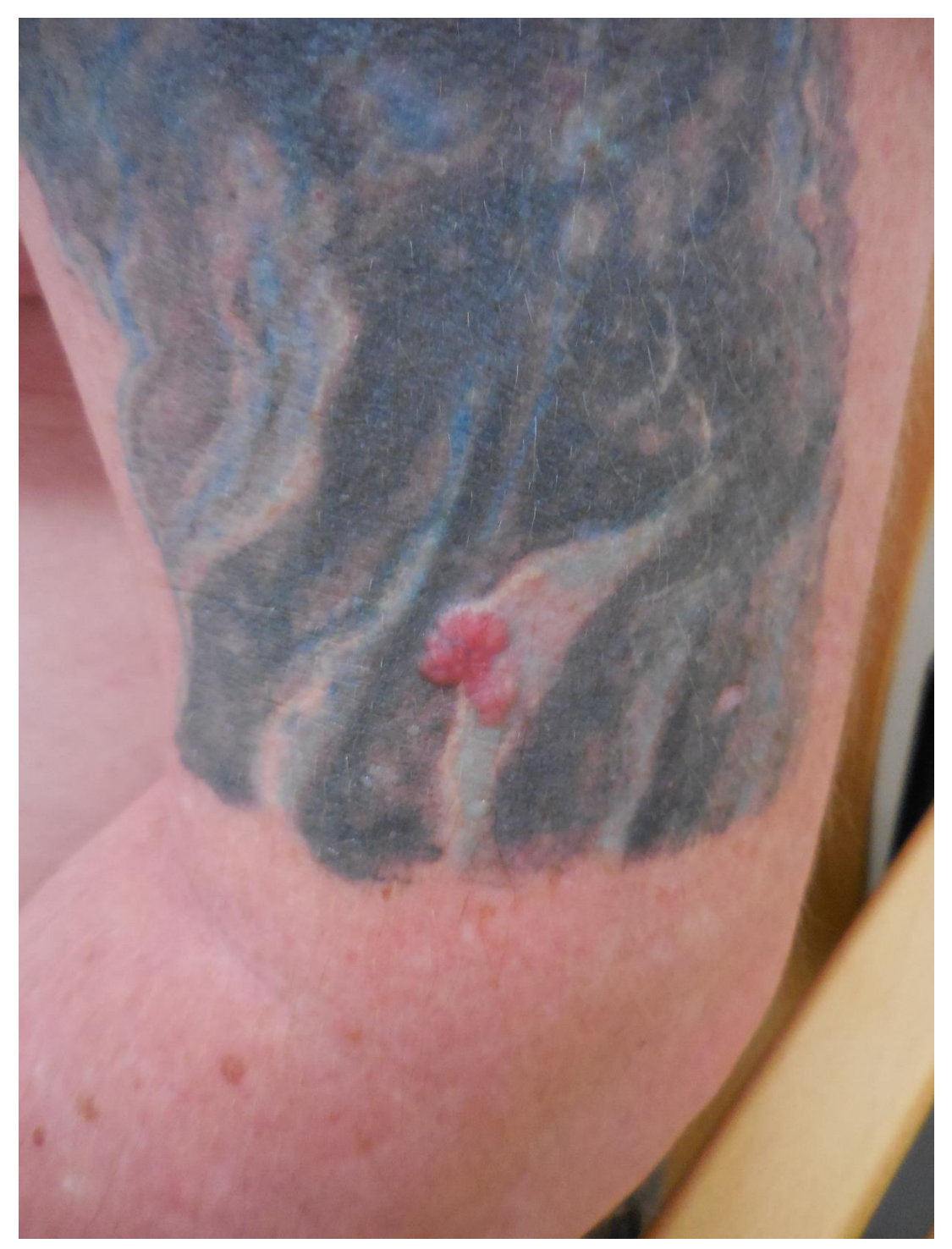

Figure 5. Patient with a basal cell carcinoma in tattooed skin [13].

Patient 4: A 52-year-old man, who was otherwise healthy, was diagnosed with a basal cell carcinoma on the right shoulder in a multi-colored tattoo (see Figure 6). No other malignancies were found during an extensive skin examination. Anamnesis revealed that the lesion was not present before placement of the tattoo. The tumor was radically excised.

Patient 5: A 50-year-old man with a medical history of multiple basal cell carcinomas, presented with four erythematous shiny plaques, in the Department of Dermatology (see Figure 7). No other malignancies were found during an extensive skin examination. Anamnesis revealed that the lesion was not present before placement of the tattoo. The histopathology of one of the lesions confirmed the suspected superficial basal cell carcinoma. The lesions were treated with topical 5-fluorouracil 5\% ointment. 


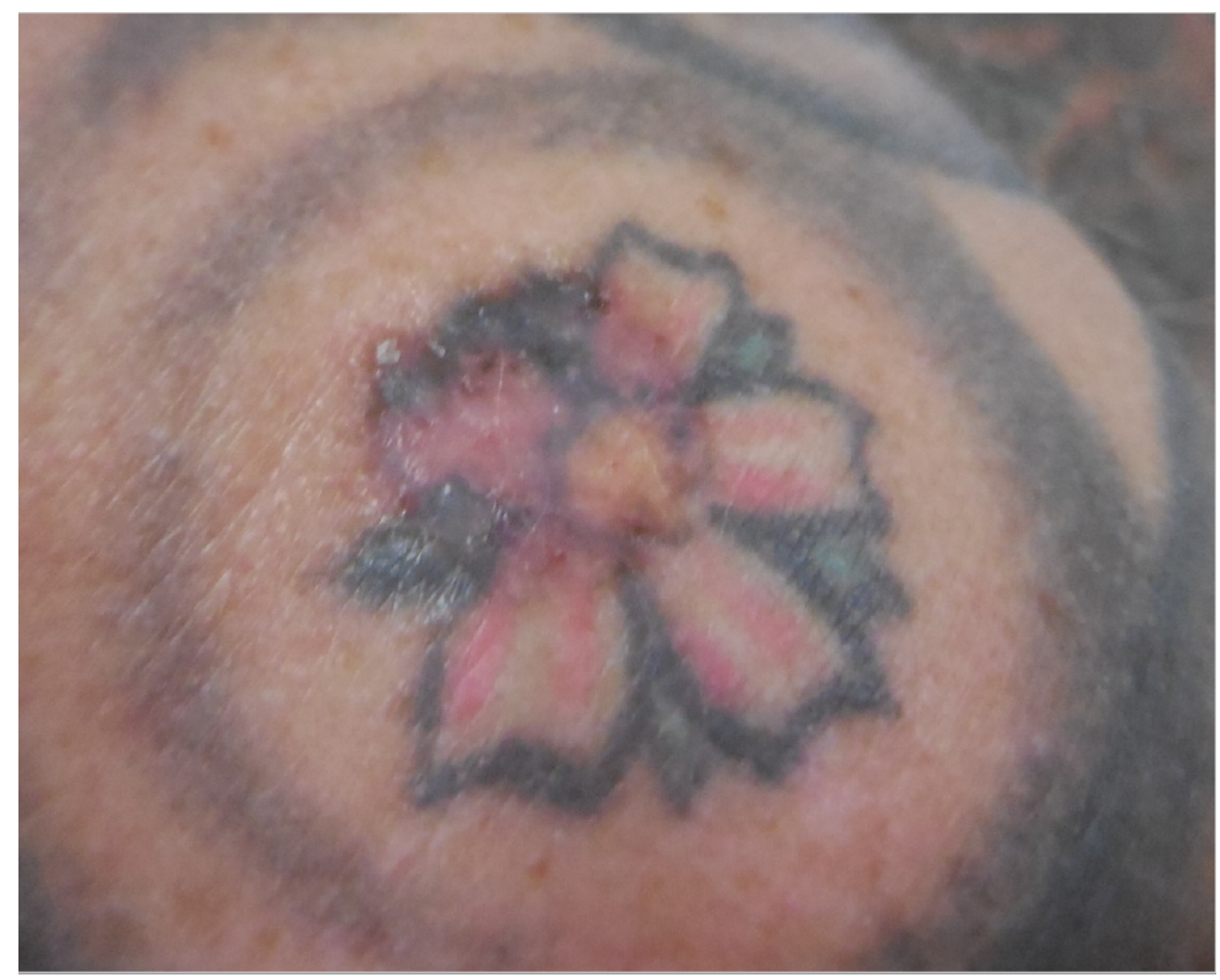

Figure 6. A nodular and superficial basal-cell carcinoma arising from red, black and green tattoo ink on the right shoulder. Reprinted from Ref. [19].

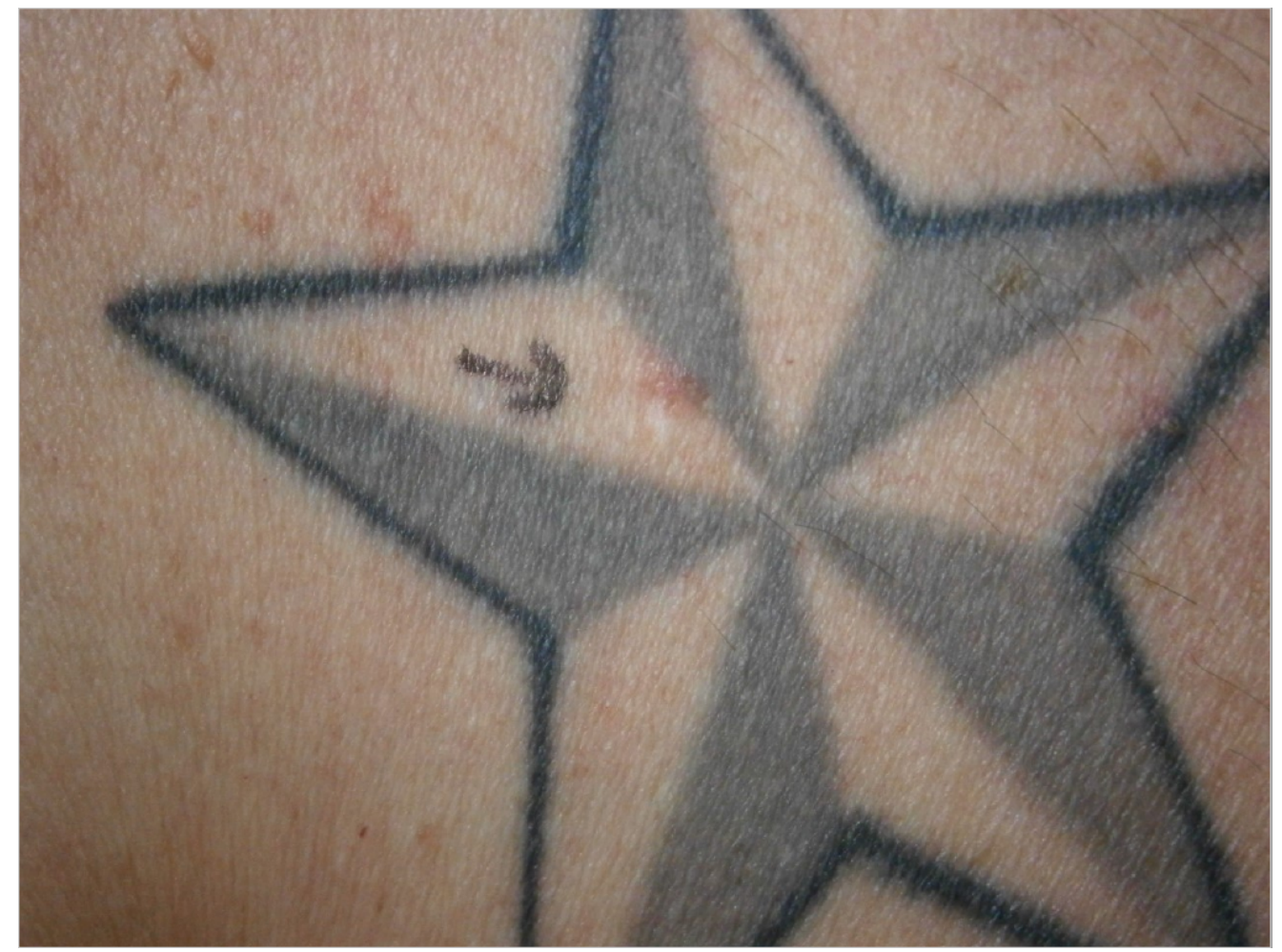

Figure 7. A patient with five shiny plaques on the back.

Patient 6: The last case is of a 60-year-old male truck driver who presented in the Department of Dermatology because of a lesion on the back (unknown time period). The 
patient's medical history revealed hypertension and the diagnosis of diabetes mellitus type 2. Furthermore, he was already diagnosed previously with BCC and SCC in an area of his neck. A physical examination revealed an asymptomatic pearly nodule with linear arborizing telangiectasis on his left back side paravertebral, in the area of a black tattoo (see Figure 8). After excision, histopathological examination confirmed the diagnosis of a nodular BCC.

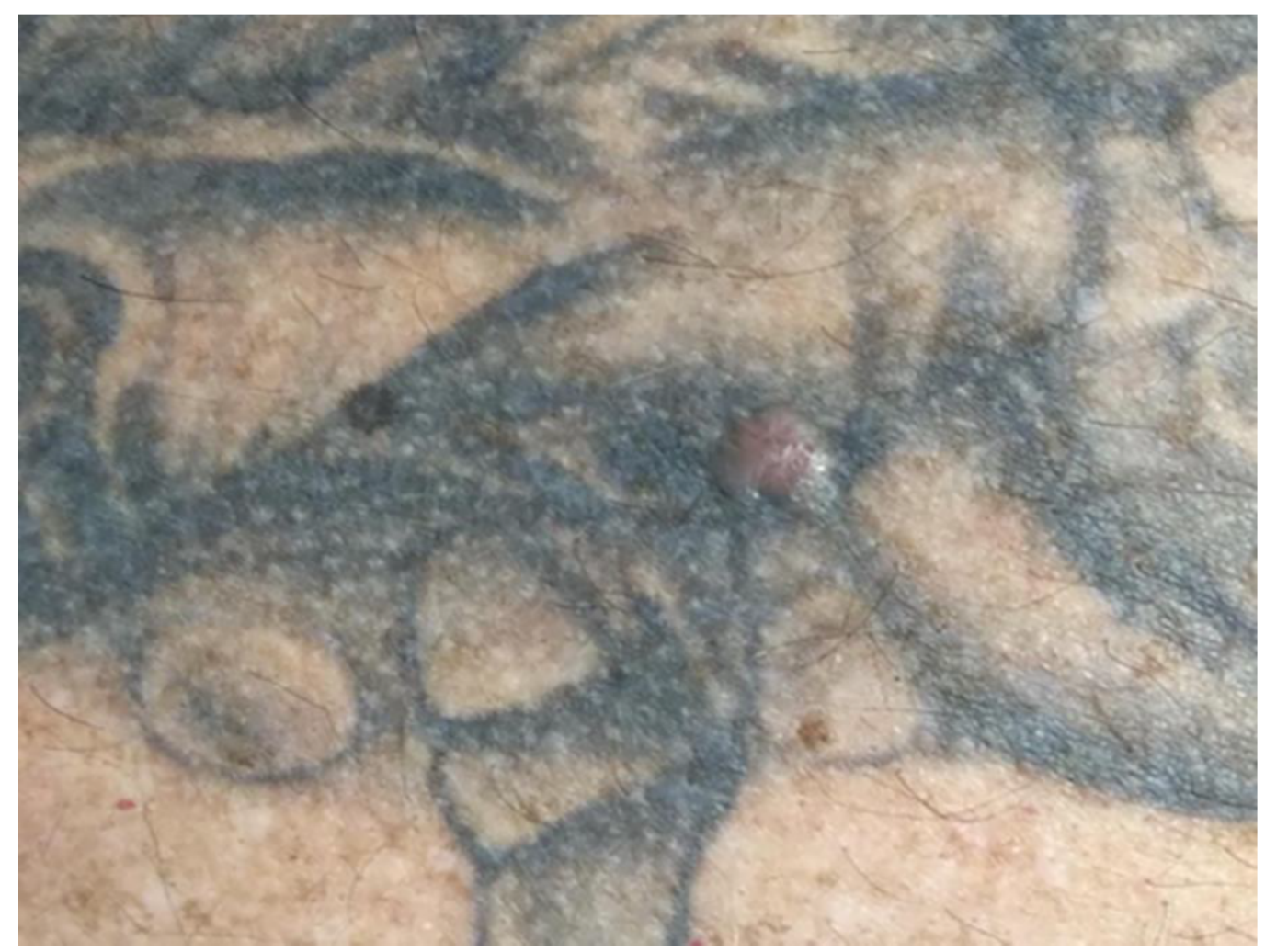

Figure 8. Patient 6: A patient with BCC on his back, paravertebral left side.

\section{Discussion}

Although the occurrence of carcinogenic substances in tattoo ink is proven, a directly causative relationship with cutaneous malignancies is unconfirmed. Including our cases, a total of 36 cases with malignant melanoma and 18 cases of basal cell carcinoma were reported. Other reported cutaneous malignancies included squamous cell carcinoma, keratoacanthoma, dermatofibrosarcoma protuberans and cutaneous leiomyosarcoma (see Table 1).

The different possible multifactorial causes for the development of skin cancer in a tattoo were documented [2,24]. First of all, the punctuation of the skin whilst tattooing is regarded as a massive skin trauma $[2,10,14]$. Furthermore, the photoallergic effects caused by the exposition of UV light to the ink ingredients, and the following chronic inflammatory reaction that occurs, could represent a possible explanation for the malignant transformation in tattoos. In addition, phototoxic effects were shown to induce hydroxyl radicals causing oxidative stress $[9,10,14,24,89]$. Aside from this, the ink compounds and their cleavage products, which are present during laser-assisted removal or UV light exposure, could act as a tumor promotor in tattooed skin $[2,14,24]$. A pyrolysis study revealed the formation of cyanide, benzene, and naphthalene as cleavage products of organic pigments, which might be comparable to the products following laser-assisted removal [90]. Other studies pointed out that the cause of tattoo-related skin reactions is not only metals (e.g., titanium, barium, aluminum and copper), which are used as colorants in older tattoo ink, but also preservatives, formulants, dispersants and impurities [81,91]. More details are presented in Table S1. Interestingly, it was revealed in the study by 
Henrik Hering et al. that fibroblasts absorb tattoo pigments and that the tattoo pigment $\mathrm{TiO} 2$ significantly decreases cell viability and increases interleukin-8 release in fibroblast monolayers [92].

An animal study, however, showed no signs of malignancy formation in mice that were extensively tattooed after $1 \mathrm{y}$ follow up, neither in the smaller subgroup of $22 \mathrm{UV}$ light-exposed animals [93]. In contrary, in another study on 99 hairless mice exposed to UV light and red tattoo ink (2-anisidine), the ink was identified as slightly cocarcinogenic when the growth rate of the second tumor increased (squamous cell carcinoma) [94].

\subsection{Melanoma and Black Tattoo Ink; Difficulties in Defining Etiopathogenesis}

In our presented cases, we report the appearance of malignant melanoma in two males with black tattoo ink. Since 1938, 36 cases with malignant melanoma have been published, from which 17 cases appeared in black tattoo ink. In our cases, the patients' tattoos contained older ink pigments, and the aforementioned carcinogenic substances might have acted as tumor promotors. Multiple hazardous compounds in black tattoo ink such as the softener substance dibutyl phthalate, hexachloro-1,3-butadiene, methenamine, dibenzofuran, benzophenone, and 9-fluorenone were confirmed in another study [95]. Especially, genotoxic polycyclic aromatic hydrocarbons dibenzofurans and 9-fluorenone, found in black tattoo ink, could act as a tumor promotor for malignant lesions in tattoos. In addition, a study showed that black tattoo ink contained nano particles and that this tattoo ink induced the cell death of fibroblasts, even in diluted form [89]. Another study found a strong association between polychlorinated biphenyls (PCBs), a compound with similar effects such as PAHs (found in older black carbon ink), and the risk of developing cutaneous malignant melanoma. In this cited study, it is suggested that PCBs act as a tumor promoter, which might promote the transformation of melanocyte clones (nevi) [96]. Likewise a higher incidence of cutaneous malignancies has been reported in PCB exposed individuals [97].

The large amounts of tattoo ink were found in tattooed skin specimens and regional lymph nodes, even years after tattooing, represented a chronic exposure. We also found the presence of tattoo ink in a lymph node with melanoma metastasis (Figure 4) [81]. Interestingly, in one of our cases of melanoma with tattoo ink (Figure 2), we found a benign melanocytic nevus component in association with black-tattoo pigmentation (Figure 3). The hypothesis that a tattoo within a benign nevus could be a risk factor for developing a melanoma is very intriguing. It might be possible that the nevus is formed following DNA damage in the melanocyte as a result of tattoo ink. We hypothesize that carcinogenic compounds in tattoo ink act as tumor promoters, which might promote the transformation of melanocyte clones (nevi) as seen in other study on PCBs [96]. Whether a melanoma is formed depends most likely on the immunological status of the individual, as well as their genetic susceptibility to DNA damage. The presence of the ink pigment in regional lymph nodes in case of metastasis also suggests the idea of a chronic exposure to the tattoo pigment in the part of the lymphatic system with a "close" relation to neoplasia.

Another possibility is the immuno-toxic effects of benzene or PAHs on the immune cells, since a higher incidence of cutaneous malignancies is reported in immunocompromised individuals [98,99]. The median age of 45 years at first diagnosis for malignant melanoma in the published tattooed individuals is lower than the age found in the general German population (60 for females and 67 for males) [100].

However, we need to keep in mind that strong evidence suggesting a causative correlation is not confirmed and the number of published cases is small.

\subsection{Basal Cell Carcinoma in Tattoo Ink and Toxicity of Injected Pigments}

We presented four cases with the formation of basal cell carcinoma. The malignancy appeared in red, green and black tattoo ink. UV-Catabolites of the red ink color differed for the used subtype and include: UV: 4-hydroxybenzamide, 4-aminobenzamide, benzamide, 4-chloroaniline, dichloroaniline, 1,4-dichlorobenzene, methoxy-naphthol AS, 2-toluidine, 
2,4,5-trichloroaniline, 2-methylformanilide, 2-methylacetanilide, 2-amino-4-nitrotoluene and 4-nitrotoluene. For green tattoo ink, no UV catabolites were identified. However, products formed during the pyrolysis of the pigment green 7 included 1,2-Benzenedicarbonitrile, benzonitrile, phthalimide [90,101-103]. For the color orange, one study showed that the formation of a similar cleavage product $\left(3,3^{\prime}\right.$-dichlorobenzidine) following the laser treatment of Pigment Orange 13 was cyto- and genotoxic [104].

Nevertheless, we must keep in mind that the toxicity of the pigment also depends on the amount of injected pigment. One study showed that the amount of injected pigment in tattoos is approximately $2.5 \mathrm{mg}$ pigment per $\mathrm{cm}^{2}$, which can create an upper arm tattoo of approximately $400 \mathrm{~cm}^{2}$. Highly tattooed people may contain even $40 \mathrm{~g}$ of pigment in their body [105], which corresponds to an enormous portion of possible harmful substances injected into the dermis. After the injection, the tissue swells (edema) followed by an influx of neutrophils and macrophages, partly phagocytizing these newly injected foreign substances. Over longer periods of chronic exposure, ink particles move to the deeper dermis (reticular dermis) and leave the skin via the dermal vessels and lymphatic system, which leads to entering the bloodstream and possible systemic effects [89]. However, the amounts of harmful compounds in the composition of tattoo inks seem highly variable between brands and colors, even in pigments with the same base color [85]. One study showed that the odds ratio of early-onset basal cell carcinoma was 1.8 at the site of the tattoo with the highest odds ratio for yellow and green [106].

The published cases contained in Table 1 show the remarkable observation that, for melanoma, 17 cases were found in black-only tattoos and 16 cases were described in colored tattoos; while in non-melanoma skin cancer, only 14 cases appeared in black-only tattoos from a total of 59 presented cases. The putative role of colored ink in non-melanoma carcinogenesis, as opposed to black ink, might necessitate further evaluation. The slightly enhanced carcinogenic potential of red ink for epithelial cancer in mice might also suggest that the carcinogenic potential of tattoo ink might be both color and tissue specific [91].

Although it is proven that tattoo ink contains harmful compounds, a causative relation between malignancies and tattoos have is unconfirmed. In addition, it should be mentioned that tattooed individuals might demonstrate a less risk-aware sun exposure habit than non-tattooed individuals, which might be another co-factor for developing skin cancer.

Mutation signatures in tattoo-associated skin cancers should be examined to separate sun-induced pathogenetic mechanisms from non-UV-induced carcinogenic mechanisms, since the mutation rate in melanomas occurring on chronically sun-exposed skin is approximately five times higher than that on skin not subject to UV exposure [107].

Long-term, prospective, epidemiologic studies on tattooed and non-tattooed individuals should be performed in order to examine a causative relationship between (cutaneous) malignancies and tattoos. The formation of melanocytic nevi in tattoos, the first step in formation of melanoma, should be examined by using photo documentation in large study groups.

\section{Conclusions}

Epidemiologically, no correlation between tattoos and the formation of malignancies is proven. However, our case series, as well as cases found in the literature research, present malignancies (malignant melanoma and basal cell carcinoma) in tattoos at a younger age compared to the epidemiologic data of general population. Furthermore, long-term, prospective research is necessary. Tattooed areas should be inspected carefully during skin examination and all cases of malignancies or other skin transformations should be reported in databases.

Supplementary Materials: The following are available online at https: / www.mdpi.com/article / 10.3390/curroncol28060398/s1, Figure S1: PRISMA 2020 flow diagramfor literature research considering tumors in tattoos. Table S1: Tattoo colorants and its cleavage products as well as possible adverse effects. 
Author Contributions: Conceptualization, M.L., S.v.d.B. and T.R.; software, M.L., H.S.; investigation, M.L., A.R., S.v.d.B., T.R., C.C.; writing-original draft preparation, M.L., H.S.; writing-review and editing, A.R., S.v.d.B., T.R., M.L., C.C.; preparation histology pictures, C.C. All authors have read and agreed to the published version of the manuscript.

Funding: This research received no external funding.

Institutional Review Board Statement: The study was conducted according to the guidelines of the Declaration of Helsinki, Ethical review and approval were waived for this study, due to its retrospective character.

Informed Consent Statement: Written and verbal Informed consent was obtained from all subjects involved in the study (except for one patient who died, no clinical pictures of this patient are shown).

Data Availability Statement: No new data were created or analyzed in this study. Data sharing is not applicable to this article.

Acknowledgments: The authors are grateful to Inge Losen and Thierry Tournassat for the excellent technical assistance.

Conflicts of Interest: The authors declare no conflict of interest.

\section{References}

1. Anforderungen der Hygiene beim Tätowieren, (2002, überarbeitet 2017). Available online: https://www.awmf.org/uploads/tx_ szleitlinien/029-0241_S1_Anforderungen-Hygiene-Taetowieren_2019-07.pdf (accessed on 24 January 2020).

2. Ricci, F.; Paradisi, A.; Maier, S.A.; Kovacs, M.; Podda, M.; Peris, K.; Abeni, D. Melanoma and tattoos: A case report and review of the literature. Eur. J. Dermatol. 2017, 28, 50-55.

3. Laumann, A.E.; Derick, A.J. Tattoos and body piercings in the United States: A national data set. J. Am. Acad. Dermatol. 2006, 55, 413-421. [CrossRef]

4. Arbeitsgemeinschaft der Wissenschaftlichen Medizinischen Fachgesellschaften-Ständige Kommission LA-RL. Leitlinienprogramm Onkologie (Deutsche Krebsgesellschaft, Deutsche Krebshilfe, AWMF): Diagnostik, Therapie und Nachsorge des Melanoms; Lang-Version 3.2. 2019:280. Available online: https:/ / www.leitlinienprogramm-onkologie.de/fileadmin/user_upload/Downloads/Leitlinien/ Melanom/Melanom_Version_3/LL_Melanom_Langversion_3.3.pdf (accessed on 24 January 2020).

5. Nolan, K.A.; Kling, M.; Birge, M.; Kling, A.; Fishman, S.; Phelps, R. Melanoma arising in a tattoo: Case report and review of the literature. Cutis 2013, 92, 227-230.

6. Statista Research Department. Weltweite Umfrage zum Tragen von Tattoos 2018 Statista Research Department: Statista Research Department; 2018. Available online: https://de.statista.com/statistik/daten/studie/864407/umfrage/weltweite-umfrage-zumtragen-von-tattoos / (accessed on 24 January 2021).

7. Kluger, N. Cutaneous complications related to permanent decorative tattooing. Expert Rev. Clin. Immunol. $2010,6,363-371$. [CrossRef] [PubMed]

8. Carlsen, K.H.; Sepehri, M.; Serup, J. Tattooist-Associated Tattoo Complications: "Overworked Tattoo", "Pigment Overload" and Infections Producing Early and Late Adverse Events. Dermatology 2020, 236, 208-215.

9. Kluger, N.; Phan, A.; Debarbieux, S.; Balme, B.; Thomas, L. Skin Cancers Arising in Tattoos: Coincidental or Not? Dermatology 2008, 217, 219-221. [CrossRef] [PubMed]

10. Lee, Y.-T.N.; Craig, J.R. Melanoma in a tattoo of the breast. J. Surg. Oncol. 1984, 25, 100-101. [CrossRef] [PubMed]

11. Huisman, S.; Van Der Bent, S.A.S.; Wolkerstorfer, A.; Rustemeyer, T. Granulomatous tattoo reactions in permanent makeup of the eyebrows. J. Cosmet. Dermatol. 2019, 18, 212-214. [CrossRef]

12. Caucanas, M.; El Hayderi, L.; Lebas, E.; Richert, B.; Dezfoulian, B.; Nikkels, A.F. Dermatological complications of temporary and indelible tattoos. Ann. Dermatol. Venereol. 2011, 138, 161-162. [CrossRef]

13. Van der Bent, S.A.; Wolkerstorfer, A.; Rustemeyer, T. Cutaneous adverse reactions to tattoos. Ned. Tijdschr. Geneeskd. 2016, 160, A9808. [PubMed]

14. Kluger, N.; Koljonen, V. Tattoos, inks, and cancer. Lancet Oncol. 2012, 13, e161-e168. [CrossRef]

15. Paradisi, A.; Capizzi, R.; De Simone, C.; Fossati, B.; Proietti, I.; Amerio, P.L. Malignant melanoma in a tattoo: Case report and review of the literature. Melanoma Res. 2006, 16, 375-376. [CrossRef] [PubMed]

16. Kuo, W.E.; Richwine, E.E.; Sheehan, D.J. Pseudolymphomatous and lichenoid reaction to a red tattoo: A case report. Cutis 2011, 87, 89-92. [PubMed]

17. Kirsch, N. Malignant melanoma developing in a tattoo. Int. J. Dermatol. 1972, 11, 16-20. [CrossRef] [PubMed]

18. van der Bent, S.A.S.; de Winter, R.W.; Wolkerstorfer, A.; Rustemeyer, T. Red tattoo reactions, a prospective cohort on clinical aspects. J. Eur. Acad. Dermatol. Venereol. 2019, 33, e384-e386. [PubMed]

19. Huisman, S.; van der Bent, S.A.; Maijer, K.I.; Tio, D.C.; Rustemeyer, T. Cutaneous non-allergic complications in tattoos: An overview of the literature. La Presse Med. 2020, 49, 104049. [CrossRef] 
20. Cherkaoui El Baraka, F.; Kluger, N.; Ollivier, I.; Bourgoin, R.; Grossin, M.; Zeboulon, C.; Phan, C.; Sin, C.; Mahé, E. Melanoma within tattoos: Two cases and a systematic literature review. Ann. Dermatol. Venereol. 2020, 147, 285-292. [CrossRef] [PubMed]

21. Deinlein, T.; Arzberger, E.; Scarfi, F.; Puches, R.F.; Hofmann-Wellenhof, R.; Zalaudek, I. A dangerous fruit of Belladonna. J. Am. Acad. Dermatol. 2016, 75, e93-e94. [CrossRef]

22. Kluger, N.; Saarinen, K. Melanoma on a tattoo. La Presse Med. 2015, 44, 473-475. [CrossRef]

23. Anthony, E.P.; Godbolt, A.; Tang, F.; McMeniman, E.K. Malignant melanoma disguised in a tattoo. Australas. J. Dermatol. 2015, 56, 232-233. [CrossRef] [PubMed]

24. JJoyce, C.W.; Duff, G.; McKenna, D.; Regan, P.J. Malignant Melanoma Arising in Red Tattoo Ink. Arch. Plast. Surg. 2015, 42, 475-477. [CrossRef] [PubMed]

25. Tchernev, G.; Chokoeva, A.A. Melanoma in a Chinese dragon tattoo. Lancet 2015. [CrossRef]

26. Caccavale, S.; Moscarella, E.; Salvatores, G.D.F.; Piccolo, V.; Russo, T.; Argenziano, G. When a melanoma is uncovered by a tattoo. Int. J. Dermatol. 2016, 55, 79-80. [CrossRef] [PubMed]

27. Kluger, N.; Koskenmies, S.; Jeskanen, L.; Övermark, M.; Saksela, O. Melanoma on Tattoos: Two Finnish Cases. Acta Derm. Venereol. 2014, 94, 325-326. [CrossRef] [PubMed]

28. Körner, R.; Pföhler, C.; Vogt, T.; Müller, C.S.L. Histopathology of body art revisited—analysis and discussion of 19 cases. J. Dtsch. Dermatol. Ges. 2013, 11, 1073-1080. [CrossRef]

29. Pohl, L.; Kaiser, K.; Raulin, C. Pitfalls and recommendations in cases of laser removal of decorative tattoos with pigmented lesions: Case report and review of the literature. JAMA Dermatol. 2013, 149, 1087-1089. [CrossRef]

30. Varga, E.; Korom, I.; Varga, J.; Kohán, J.; Kemény, L.; Oláh, J. Melanoma and melanocytic nevi in decorative tattoos: Three case reports. J. Cutan. Pathol. 2011, 38, 994-998. [CrossRef]

31. Jaigirdar, A.A.; Yeh, M.W.; Sharifi, E.; Browne, L.W.; Leong, S.P. Coexisting Tattoo Pigment and Metastatic Melanoma in the Same Sentinel Lymph Node. J. Cutan. Med. Surg. 2009, 13, 321-325. [CrossRef]

32. Singh, R.S.; Diwan, A.H.; Prieto, V.G. Potential diagnostic pitfalls in melanoma arising in a cutaneous tattoo. Histopathology 2007, 51, 283-285. [CrossRef]

33. Shariff, Z.; Tehrani, H.; Jagadeesan, J.; Hardwicke, J. Artwork: To be studied. Dermatol. Online J. 2006, 12, 21. [CrossRef]

34. Stinco, G.; De Francesco, V.; Frattasio, A.; Quinkenstein, E.; Patrone, P. Malignant Melanoma in a Tattoo. Dermatology 2003, 206, 345-346. [CrossRef]

35. Khan, I.U.; Moiemen, N.S.; Firth, J.; Frame, J.D. Malignant melanoma disguised by a tattoo. Br. J. Plast. Surg. 1999, $52,598$. [CrossRef] [PubMed]

36. Soroush, V.; Gurevitch, A.W.; Peng, S.K. Malignant melanoma in a tattoo: Case report and review of the literature. Cutis 1997, 59, 111-112. [PubMed]

37. Kircik, L.; Armus, S.; van den Broek, H. Malignant melanoma in a tattoo. Int. J. Dermatol. 1993, 32, 297-298. [CrossRef] [PubMed]

38. Bartal, A.H.; Cohen, Y.; Robinson, E. Malignant melanoma arising at tattoo sites used for radiotherapy field marking. Br. J. Radiol. 1980, 53, 913-914. [CrossRef] [PubMed]

39. Wolfort, F.C.; Hoopes, J.E.; Filtze, H.S.; Cochran, T.C. Superficial melanoma in a tattoo. Br. J. Plast. Surg. 1974, $27,303-304$. [CrossRef]

40. Allen, A.C. The Skin: A Clinicopathologic Treatise; The CV Mosby Company: St. Louis, MO, USA, 1954.

41. Sharlit, H. Melanoma caused by indelible pencil. Arch. Dermatol. 1938, 37, 301-306. [CrossRef]

42. Edmonds, N.; Cropley, T.; Noland, M.; Flowers, R. Basal cell carcinoma arising in a tattoo. Clin. Dermatol. Rev. 2020, 4, 167-169.

43. Abudu, B.; Erickson, C.P.; Calame, A.; Cohen, P.R. Basal Cell Carcinoma Originating in a Tattoo: Case Report and Review of an Uncommon Complication in Tattoo Recipients. Dermatol. Pract. Concept. 2019, 9, 265-270. [CrossRef] [PubMed]

44. Messmer, E.M.; Mohring-Bengisu, C.; Miller, C. Lidline Tattoo Associated with Basal Cell Carcinoma of the Lid MarginCoincidence or Association? Klin. Monbl. Augenheilkd. 2018, 235, 785-788.

45. Omidian, M.; Emad-Mostofi, N. Basal cell carcinoma arising from traditional tattoo. Arch. Iran. Med. 2009, 12, 198. [PubMed]

46. Lee, J.-S.; Park, J.; Kim, S.-M.; Yun, S.-K.; Kim, H.-U. Basal Cell Carcinoma Arising in a Tattooed Eyebrow. Ann. Dermatol. 2009, 21, 281-284. [CrossRef] [PubMed]

47. Birnie, A.J.; Kulkarni, K.; Varma, S. Basal cell carcinoma arising in a tattoo. Clin. Exp. Dermatol. 2006, 31, 820-821. [CrossRef] [PubMed]

48. Doumat, F.; Kaise, W.; Barbaud, A.; Schmutz, J. Basal Cell Carcinoma in a Tattoo. Dermatology 2004, 208, 181-182. [CrossRef] [PubMed]

49. Wiener, D.A.; Scher, R.K. Basal cell carcinoma arising in a tattoo. Cutis 1987, 39, 125-126. [PubMed]

50. Earley, M. Basal cell carcinoma arising in tattoos: A clinical report of two cases. Br. J. Plast. Surg. 1983, 36, 258-259. [CrossRef]

51. Shrout, M.; DeCoster, R.; Wermeling, R.; Vasconez, H.C. Risk Factors for Squamous Cell Carcinoma: A Case for Red Pigment in Tattoos. Am. Surg. 2019, 85, e77-e78. [CrossRef] [PubMed]

52. Paprottka, F.J.; Krezdorn, N.; Narwan, M.; Turk, M.; Sorg, H.; Noah, E.M.; Hebebrand, D. Trendy Tattoos-Maybe a Serious Health Risk? Aesthetic Plast. Surg. 2017, 42, 310-321. [CrossRef] [PubMed]

53. Sherif, S.; Blakeway, E.; Fenn, C.; German, A.; Laws, P. A Case of Squamous Cell Carcinoma Developing Within a Red-Ink Tattoo. J. Cutan. Med. Surg. 2016, 21, 61-63. [CrossRef] 
54. Maxim, E.; Higgins, H.; D'Souza, L. A case of multiple squamous cell carcinomas arising from red tattoo pigment. Int. J. Women's Dermatol. 2017, 3, 228-230. [CrossRef]

55. Schmitz, I.; Prymak, O.; Epple, M.; Ernert, C.; Tannapfel, A. Squamous cell carcinoma in association with a red tattoo. J. Dtsch. Dermatol. Ges. 2016, 14, 604-609. [CrossRef] [PubMed]

56. Barton, D.T.; Karagas, M.R.; Samie, F.H. Eruptive Squamous Cell Carcinomas of the Keratoacanthoma Type Arising in a Cosmetic Lip Tattoo. Dermatol. Surg. 2015, 41, 1190-1193. [CrossRef] [PubMed]

57. Paprottka, F.J.; Bontikous, S.; Lohmeyer, J.A.; Hebebrand, D. Squamous-cell Carcinoma Arises in Red Parts of Multicolored Tattoo within Months. Plast. Reconstr. Surg.-Glob. Open 2014, 2, e114. [CrossRef] [PubMed]

58. Sarma, D.P.; Dentlinger, R.B.; Forystek, A.M.; Stevens, T.; Huerter, C. Poorly Differentiated Squamous Cell Carcinoma Arising in Tattooed Skin. Case Rep. Med. 2010, 2010, 431813. [CrossRef]

59. Ortiz, A.; Yamauchi, P.S. Rapidly growing squamous cell carcinoma from permanent makeup tattoo. J. Am. Acad. Dermatol. 2009, 60, 1073-1074. [CrossRef]

60. Goldenberg, G.; Patel, S.; Patel, M.J.; Williford, P.; Sangueza, O. Eruptive squamous cell carcinomas, keratoacanthoma type, arising in a multicolor tattoo. J. Cutan. Pathol. 2007, 35, 62-64. [CrossRef] [PubMed]

61. Pitarch, G.; Martínez-Menchón, T.; Martínez-Aparicio, A.; Sánchez-Carazo, J.L.; Muñoz, D.; Fortea, J.M. Squamous cell carcinoma over tattoos. J. Am. Acad. Dermatol. 2007, 56, 1072-1073. [CrossRef]

62. McQuarrie, D.G. Squamous-cell carcinoma arising in a tattoo. Minn. Med. 1966, 49, 799-801. [PubMed]

63. Colboc, H.; Bazin, D.; Moguelet, P.; Reguer, S.; Amode, R.; Jouanneau, C.; Lucas, I.; Deschamps, L.; Descamps, V.; Kluger, N. Chemical composition and distribution of tattoo inks within tattoo-associated keratoacanthoma. J. Eur. Acad. Dermatol. Venereol. 2020, 34, e313-e315. [CrossRef] [PubMed]

64. Giornale Italiano di Dermatologia e Venereologia 2019 Sep 30. Available online: https:/ /www.minervamedica.it/en/journals / Ital-J-Dermatol-Venereol/article.php?cod=R23Y9999N00A19093001\&acquista=1 (accessed on 24 January 2020).

65. Kluger, N.; Douvin, D.; Dupuis-Fourdan, F.; Doumecq-Lacoste, J.M.; Descamps, V. Keratoacanthomas on recent tattoos: Two cases. Ann. Dermatol. Venereol. 2017, 144, 776-783. [CrossRef]

66. Fraga, G.R.; Prossick, T.A. Tattoo-associated keratoacanthomas: A series of 8 patients with 11 keratoacanthomas. J. Cutan. Pathol. 2010, 37, 85-90. [CrossRef] [PubMed]

67. Gon Ados, S.; Minelli, L.; Meissner, M.C. Keratoacanthoma in a tattoo. Dermatol. Online J. 2009, 15, 9. [PubMed]

68. Kluger, N.; Minier-Thoumin, C.; Plantier, F. Keratoacanthoma occurring within the red dye of a tattoo. J. Cutan. Pathol. 2008, 35, 504-507. [CrossRef] [PubMed]

69. De Antoni, E.; Brambullo, T.; Pescarini, E.; Salmaso, R.; Bassetto, F.; Vindigni, V. Dermatofibrosarcoma Protuberans on Tattooed Skin: A Case Report. Adv. Skin Wound Care 2020, 33, 104-108. [CrossRef] [PubMed]

70. Lastrucci, I.; Gunnella, S.; Pileri, A.; Maio, V.; Grandi, V. Dermatofibrosarcoma protuberans secondary to a decorative tattoo: An Isotattootopic Response? Indian J. Dermatol. 2018, 63, 439. [CrossRef] [PubMed]

71. Lobato-Berezo, A.; Churruca-Grijelmo, M.; Martínez-Pérez, M.; Imbernón-Moya, A.; Vargas-Laguna, M.E.; Fernández-Cogolludo, E.; Aguilar-Martínez, A.; Gallego-Valdés, M. Ángel Dermatofibroma Arising within a Black Tattoo. Case Rep. Dermatol. Med. 2014, 2014, 745304. [PubMed]

72. Reddy, K.K.; Hanke, C.W.; Tierney, E.P. Malignancy arising within cutaneous tattoos: Case of dermatofibrosarcoma protuberans and review of literature. J. Drugs Dermatol. 2011, 10, 837-842.

73. Baker, P.A.; O’Dowd, G.J.; Khan, I.U. Dermatofibrosarcoma Protuberans Arising in a Decorative Tattoo. Sarcoma 2005, 9, 37-41. [CrossRef]

74. Souza, E.S.; Rocha Bde, O.; Batista Eda, S.; Oliveira, R.F.; Farre, L.; Bittencourt, A.L. T-cell-predominant lymphoid hyperplasia in a tattoo. An. Bras. Dermatol. 2014, 89, 1019-1021. [CrossRef] [PubMed]

75. Moulonguet, I.; Garçon, N.; Rivet, J.; Cavelier-Balloy, B. Nodule developing over a tattoo: Challenge. Cutaneous lymphoid hyperplasia (pseudolymphoma). Am. J. Dermatopathol. 2014, 36, 101-102. [CrossRef]

76. Bouchy, C.G.; Kerdraon, R.; Kluger, N.; Armingaud, P.; Wakosa, A.; Estève, E. Cutaneous lymphoid hyperplasia (pseudolymphoma) on the red dye of a tattoo. Ann. Pathol. 2013, 33, 273-277.

77. Pasolini, G.; Ghidini, P.; Arisi, M.; Pedretti, A.; Ungari, M.; Pinton, P.C. Pseudolymphoma tattoo-induced. Dermatol. Rep. 2011, 3, e47. [CrossRef] [PubMed]

78. Chiang, C.; Romero, L. Cutaneous Lymphoid Hyperplasia (Pseudolymphoma) in a Tattoo After Far Infrared Light. Dermatol. Surg. 2009, 35, 1434-1438. [CrossRef]

79. Mahalingam, M.; Kim, E.; Bhawan, J. Morphea-Like Tattoo Reaction. Am. J. Dermatopathol. 2002, 24, 392-395. [CrossRef] [PubMed]

80. West, C.C.; Morritt, A.N.; Pedelty, L.; Lam, D.G. Cutaneous leiomyosarcoma arising in a tattoo-A tumour with no humour. J. Plast. Reconstr. Aesthetic Surg. 2009, 2, e79-e80. [CrossRef] [PubMed]

81. Laux, P.; Tralau, T.; Tentschert, J.; Blume, A.; Al Dahouk, S.; Bäumler, W.; Bernstein, E.; Bocca, B.; Alimonti, A.; Colebrook, H.; et al. A medical-toxicological view of tattooing. Lancet 2016, 387, 395-402. [CrossRef]

82. Humphries, A.; Lister, T.S.; Wright, P.A.; Hughes, M.P. Determination of the thermal and physical properties of black tattoo ink using compound analysis. Lasers Med. Sci. 2013, 28, 1107-1112. [CrossRef]

83. Carlsen, K.H.; Sepehri, M. Tattoo Complaints and Complications: Diagnosis and Clinical Spectrum. Curr. Probl. Dermatol. 2015, $48,48-60$. 
84. Beute, T.C.; Miller, C.H.; Timko, A.L.; Ross, E.V. In vitro spectral analysis of tattoo pigments. Dermatol. Surg. 2008, 34, 508-515.

85. Forte, G.; Petrucci, F.; Cristaudo, A.; Bocca, B. Market survey on toxic metals contained in tattoo inks. Sci. Total Environ. 2009, 407, 5997-6002. [CrossRef] [PubMed]

86. Bil, W.; Van Der Bent, S.A.S.; Spiekstra, S.; Nazmi, K.; Rustemeyer, T.; Gibbs, S. Comparison of the skin sensitization potential of 3 red and 2 black tattoo inks using interleukin-18 as a biomarker in a reconstructed human skin model. Contact Dermat. 2018, 79, 336-345. [CrossRef] [PubMed]

87. Hauri, U.; Hohl, C. Photostability and Breakdown Products of Pigments Currently Used in Tattoo Inks. Curr. Probl. Dermatol. 2015, 48, 164-169. [PubMed]

88. Kluger, N. Tattoo Reactions Associated with Targeted Therapies and Immune Checkpoint Inhibitors for Advanced Cancers: A Brief Review. Dermatology 2019, 235, 522-524. [CrossRef] [PubMed]

89. Grant, C.A.; Twigg, P.C.; Baker, R.; Tobin, D.J. Tattoo ink nanoparticles in skin tissue and fibroblasts. Beilstein J. Nanotechnol. 2015, 6, 1183-1191. [CrossRef] [PubMed]

90. Schreiver, I.; Hutzler, C.; Andree, S.; Laux, P.; Luch, A. Identification and hazard prediction of tattoo pigments by means of pyrolysis-gas chromatography/mass spectrometry. Arch. Toxicol. 2016, 90, 1639-1650. [CrossRef] [PubMed]

91. Jacobsen, E.T.K.; Pedersen, E. Chemical Substances in Tattoo Ink; Danish Environmental Protection Agency Danish Environmental Protection Agency: Copenhagen, Danish, 2012.

92. Hering, H.; Zoschke, C.; Kühn, M.; Gadicherla, A.K.; Weindl, G.; Luch, A.; Schreiver, I. TatS: A novel in vitro tattooed human skin model for improved pigment toxicology research. Arch. Toxicol. 2020, 94, 2423-2434. [CrossRef] [PubMed]

93. Sepehri, M.; Lerche, C.M.; Carlsen, K.H.; Serup, J. Search for Internal Cancers in Mice Tattooed with Inks of High Contents of Potential Carcinogens: A One-Year Autopsy Study of Red and Black Tattoo Inks Banned in the Market. Dermatology 2017, 233, 94-99. [CrossRef] [PubMed]

94. Lerche, C.M.; Heerfordt, I.M.; Serup, J.; Poulsen, T.; Wulf, H.C. Red tattoos, ultraviolet radiation and skin cancer in mice. Exp. Dermatol. 2017, 26, 1091-1096. [CrossRef]

95. Lehner, K.; Santarelli, F.; Vasold, R.; König, B.; Landthaler, M.; Bäumler, W. Black tattoo inks are a source of problematic substances such as dibutyl phthalate. Contact Dermat. 2011, 65, 231-238. [CrossRef]

96. Gallagher, R.P.; MacArthur, A.C.; Lee, T.K.; Leblanc, A.; Elwood, J.M.; Borugian, M.; Abanto, Z.; Spinelli, J.J.; Weber, J.-P. Plasma levels of polychlorinated biphenyls and risk of cutaneous malignant melanoma: A preliminary study. Int. J. Cancer 2010, 128, 1872-1880. [CrossRef]

97. Leijs, M.M.; Esser, A.; Amann, P.M.; Schettgen, T.; Gube, M.; Merk, H.F.; Kraus, T.; Baron, J.M. Hyperpigmentation and higher incidence of cutaneous malignancies in moderate-high PCB- and dioxin exposed individuals. Environ Res. 2018, 164, $221-228$. [CrossRef] [PubMed]

98. Gallagher, M.P.; Kelly, P.J.; Jardine, M.; Perkovic, V.; Cass, A.; Craig, J.; Eris, J.; Webster, A. Long-Term Cancer Risk of Immunosuppressive Regimens after Kidney Transplantation. J. Am. Soc. Nephrol. 2010, 21, 852-858. [CrossRef] [PubMed]

99. Sauer, E.; Gauer, B.; Nascimento, S.; Nardi, J.; Göethel, G.; Costa, B.; Correia, D.; Matte, U.; Charão, M.; Arbo, M.; et al. The role of B7 costimulation in benzene immunotoxicity and its potential association with cancer risk. Environ. Res. 2018, 166, 91-99. [CrossRef] [PubMed]

100. Malignes Melanom: Schwarzer Hautkreb. Available online: https://www.krebsgesellschaft.de/onko-internetportal/basisinformationen-krebs/krebsarten/hautkrebs/malignes-melanom-schwarzer-hautkrebs.html (accessed on 21 January 2021).

101. Vasold, R.; Naarmann, N.; Ulrich, H.; Fischer, D.; Konig, B.; Landthaler, M.; Bäumler, W. Tattoo pigments are cleaved by laser light-the chemical analysis in vitro provide evidence for hazardous compounds. Photochem. Photobiol. 2004, 80, 185-190. [CrossRef] [PubMed]

102. Wezel, K. Untersuchung des Verhaltens von Tätowiertinten und Pigmenten unter Lichteinfluss. Master's Thesis, University of Giessen, Giessen, Germany, 2013.

103. Gaugler, S. Analysis of bioactive compounds in tattoo inks before and after irradiation with sunlight using HPTLC and in situ detection with vibrio fischeri. Master's Thesis, University of Hohenheim, Stuttgart, Germany, 2011.

104. Hering, H.; Sung, A.Y.; Röder, N.; Hutzler, C.; Berlien, H.-P.; Laux, P.; Luch, A.; Schreiver, I. Laser Irradiation of Organic Tattoo Pigments Releases Carcinogens with 3,3'-Dichlorobenzidine Inducing DNA Strand Breaks in Human Skin Cells. J. Investig. Dermatol. 2018, 138, 2687-2690. [CrossRef] [PubMed]

105. Schreiver, I.; Luch, A. At the dark end of the rainbow: Data gaps in tattoo toxicology. Arch. Toxicol. 2016, 90, 1763-1765. [CrossRef] [PubMed]

106. Barton, D.T.; Zens, M.S.; Marmarelis, E.L.; Gilbert-Diamond, D.; Karagas, M.R. Cosmetic Tattooing and Early Onset Basal Cell Carcinoma: A Population-based Case-Control Study from New Hampshire. Epidemiology 2020, 31, 448-450. [CrossRef] [PubMed]

107. Palmieri, G. Italian Melanoma Intergroup for the Italian Melanoma Intergroup (IMI); Colombino, M.; Casula, M.; Manca, A.; Mandalà, M.; Cossu, A. Molecular Pathways in Melanomagenesis: What We Learned from Next-Generation Sequencing Approaches. Curr. Oncol. Rep. 2018, 20, 86. [CrossRef] 